\title{
Defending the Concept of Time in the Hebrew Bible
}

Bundvad, Mette

Published in:

SJOT (Scandinavian Journal of the Old Testament)

DOI:

$10.1080 / 09018328.2014 .932575$

Publication date:

2014

Document version

Early version, also known as pre-print

Document license:

Other

Citation for published version (APA):

Bundvad, M. (2014). Defending the Concept of Time in the Hebrew Bible. SJOT (Scandinavian Journal of the Old Testament), 28(2), 280-297. https://doi.org/10.1080/09018328.2014.932575 


\title{
Defending the Concept of Time in the Hebrew Bible
}

\author{
Mette Bundvad \\ Department of Biblical Studies, the Theological Faculty, \\ The University of Copenhagen \\ Kobmagergade 44-46, DK-1150 Copenhagen K, Denmark \\ Email: mette.bundvad@theologie.uni-goettingen.de
}

\begin{abstract}
Due to the scarcity of reflection on time as an independent subject in the Hebrew Bible, there has been a scholarly tendency to consider biblical time conception more limited than our own-perhaps even non-existent. This article confronts the scholarly skepticism regarding the ability of the biblical authors to think about time, defending the presence of time conceptualization in the Hebrew Bible. In the article I discuss central research contributions to the subject of biblical time, in particular Sacha Stern's thesis that the concept of time is entirely absent from the Hebrew Bible and from ancient Judaism more widely. I explore linguistic and anthropological assumptions which underpin large parts of the discussion on time within biblical studies, arguing that one cannot assume on the basis of either that the biblical authors lacked a concept of time. Finally, I suggest that the ability of the biblical writers to coordinate unrelated processes according to a temporal axis is a strong argument in favour of their awareness of time.
\end{abstract}

Key words: biblical time-conception, time-anthropology, linguistic relativism, time and process

\section{Introduction}

Quoting Augustine's exasperated attempt to put into words the human experience of time is an almost irresistible temptation. Every academic working on time seems to do it. Augustine writes in his Confessions:

"What, then, is time? I know well enough what it is, provided that nobody asks me; but if I am asked what it is and try to explain, I am baffled." 1

Perhaps its very resistance makes the concept of time all the more fascinating as a subject of reflection: how can something which seems so fundamental to

1. Yes, I fell for it too. Augustine, Confessions 11.14.17. Translated by R. S. PineCoffin (Harmondsworth: Penguin, 1961). 
our life-experience be this difficult to engage with? In the specific context of the Hebrew Bible there is, I think, a related reason why some academic interpreters have found time such an attractive subject of study: on the one hand, temporal notions and thinking on time appear vital to the constructions of theology taking place within its pages. ${ }^{2}$ There is a rich vocabulary of temporal terms in the Hebrew Bible, ${ }^{3}$ and a wide range of themes related to time stand centrally throughout most of this literary corpus. On the other hand, there is virtually no discussion of time as a subject of reflection in its own right. Scholars have pointed out that the temporal expressions which $d o$ occur frequently seem very concrete: they appear to describe time especially as it is characterized by particular activities or experiences. ${ }^{4}$ Time-talk is always difficult, but the biblical near-absence of reflection on time as an independent subject raises additional questions: to what extent does the textual material enable us to discuss how the biblical authors conceptualized time? Can we even be sure that it is really time which they discuss when time-related issues such as mortality, calendar, and history take to the stage?

There has been a tendency in scholarship to consider biblical time conception not just different from our own, but also more limited - or perhaps even non-existent. In this article I hope to show that this skepticism regarding the ability of the Hebrew Bible authors to conceptualize time, which persists in some recent research contributions, is not warranted. After outlining some important research contributions to the subject of biblical time, I evaluate the linguistic and anthropological assumptions which underpin significant parts of the current scholarly conversation on this subject. ${ }^{5}$ Finally, I suggest a few alternative routes into the biblical material on time.

2. For example, Genesis 1,14-15 ties the creation of sun and moon to the establishment of calendar and time-reckoning. At the end of the Yahwist's flood story, God reiterates his promise that the seasons of the world shall remain predictable and stable (Genesis 8,22 ). Is aiah 42,9 and 43,18 connect the human and the divine history in tantalizingly vague references to the former works of the deity and the new things now decreed. The Psalms too offer a wide range of reflections on temporal matters - especially those related to mortality, and to the different temporal realities of God and human being (see for example Ps. 39,5-6 and Ps 90,4). Finally, the wisdom literature goes further than any other genre in the Hebrew Bible in discussing, quite explicitly, the temporal organization of the world, as well as the human experience of life within these temporal structures (see for example Qohelet 1,4-11; 3,1-11.14-15, and 7,13-14).

3. These terms are the focus of Gershon Brin's detailed monograph on time in the Hebrew Bible and at Qumran. (Gershon Brin, The Concept of Time in the Bible and the Dead Sea Scrolls [Leiden: Brill, 2001]).

4. So for example John Marsh, The Fulness of Time (London: Nisbet \& Co., 1952), especially pp. 19-34. E. Trocmé in J. J. von Allmen (ed), Vocabulary of the Bible (Lutterworth Press: London, 1958), pp. 423-426, and Henry Wheeler Robinson, Inspiration and Revelation in the Old Testament (Oxford: Clarendon Press, 1946), especially pp. 106-112.

5. Within the confines of the article format, it is unfortunately not possible to survey all scholarly approaches to the subject of time in the Hebrew Bible. I have focused on research contributions which-because of their centrality to the scholarly conversation 


\section{A Biblical Concept of Time?}

The research field of biblical time conception blossomed especially in the fifties and sixties, and it is currently experiencing a reawakening. ${ }^{6}$ While prominent scholars in the middle of the twentieth century discussed especially the possibility that the Hebrew Bible writers had a different, and possibly more limited, conception of time than we do in the Western world today, some of the more recent research contributions raise the bar even higher. Perhaps most radically, Sacha Stern argues that the biblical authors were not in possession of a functional concept of time at all. ${ }^{7}$ Stern's work will be the main focus of this article, as it poses an enormous challenge to explorations of biblical time conception. Initially, however, I turn to the lexical approach of the mid-twentieth century. This was the first big wave of research into biblical time, and although it has largely been abandoned it forms an important backdrop to the more recent engagements with the subject of time in the Bible.

Proponents of the lexical approach expected the lay-out of the Hebrew language, especially its lexical stock, to reveal how the biblical authors conceptualized certain notions, such as time. They would argue that the time-conception of the biblical writers was reflected in and perhaps even predicated on their language. According to this line of thinking, there was a particular Hebrew conception of time which a careful investigation of the Hebrew lexical stock would allow us to discover. Thus, for example, John Marsh suggested that there was a difference between ancient Hebrew and Greek thinking on time,

on the topic and because of their use of related methodological approaches - can easily be brought into conversation with each other. I seek primarily to addres s a sometimes present scholarly skepticism regarding the presence and extent of time conception in the Hebrew Bible and consequently also our ability to engage with the concept of time as it manifests in the Bible.

6. Especially worth mentioning are the recent monographs on time in the Hebrew Bible and the wider ancient Jewish context by Brin (The Concept of Time) and Sacha Stern (Time and Process in Ancient Judaism [Oxford: Littman Library of Jewish Civilization, 2003]). Studies on time in individual books have also started appearing, for example Mette Bundvad on Qohelet (Time in the Book of Qohelet [Oxford University Press, forthcoming]). Finally, a number of shorter studies on particular aspects of temporal thinking in various, biblical contexts show the potential diversity of the subject area (for example Peter Machinist on fate and occurrence (Peter Machinist, "Fate, miqreh, and Reason: Some Reflections on Qohelet and Biblical Thought," in Z. Zevit, S. Gitin, and M. Sokoloff (eds), Solving Riddles and Untying Knots: Biblical, Epigraphic, and Semitic Studies in Honor of Jonas C. Greenfield [Winona Lake: Eisenbrauns, 2005], pp. 159-175.) and Mattias Köchert on time and eternity in Psalm 90 (Mattias Köchert, "Zeit und Ewigkeit in Psalm 90," in R. G. Kratz and H. Spieckermann (eds), Zeit und Ewigkeit als Raum göttlichen Handelns: Religionsgeschichtliche, theologische und philosophische Perspektiven [BZAW, 390; Berlin: Walter de Gruyter, 2009], pp. 155-185).

7. Stern, Time and Process. 
related directly to the words for time which were available in the two languages. ${ }^{8}$ Similarly, Oscar Cullmann argued in favour of a distinction between the Greek conception of time, which understood time as an eternal cycle, and the biblical understanding of time as an upwards-sloping line. ${ }^{9}$

In Biblical Words for Time James Barr launched a comprehensive critique of the lexical approach. ${ }^{10}$ His attack was two-pronged: firstly, he questioned the accuracy of the distinctions assumed between the thinking on time within different language groups. For example, he pointed out the presence of cyclical time-conception in Hebrew, as well as linear views on time in Greek material. ${ }^{11}$

8. Marsh, The Fulness ofTime, p. 20. Marsh argues that biblical time is "realistic time": time distinguished by its content rather than its chronological position. He argues that

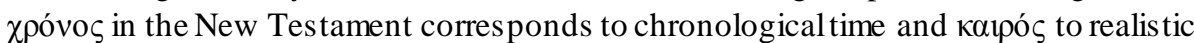
time, Kalpó $\varsigma$ being the appropriate translation of the Hebrew עת. A much more recent piece of research by Tilmann Zimmer (Zwischen Tod und Lebensglück. Eine Untersuchung zur Anthropologie Kohelets [Berlin: Walter de Gruyter, 1999]) champions a similar view of Hebrew time conception as predominately concrete, see especially $\mathrm{p}$. 82.

9. Oscar Cullmann, Christ and Time (London: SCM Press, 1962), p. 52. In a somewhat related manner, Jürgen Ebach draws attention to the fact that the Hebrew words for past can also mean "face" or "front" (פנים, esp.in connection with the preposition ל as well as קדם (אחרן), while the Hebrew word for future can mean "back-side" or "behind" (אחרון/אחרית) (see: Jürgen Ebach, Ursprung und Ziel: Erinnerte Zukunft und erhoffte Vergangenheit. Biblische Exegesen, Reflexionen, Geschichten [Neukirchen-Vluyn: Neukirschener Verlag, 1986], pp. 51-53). This lexical feature allegedly demonstrates that the past was conceived by the Hebrews as that which lies in front of us, accessible and visible. In connection with this particular claim, it is important to note that this distribution (future/behind-past/front) is far from unique to Hebrew, rendering it unlikely at least that a particularly Hebrew conception of past and future could be discovered on the basis of these words and their lexical potential. For example, in Latin anterior can be used both temporally and about that which is in front of or before something, and posterior similarly both temporally and about that which is behind. Hans Walter Wolff notes that something similar may be true in German regarding the words Vorfahren and Nachfahren. (Hans Walter Wolff, Anthropologie des Alten Testaments. München: Chr. Kaiser Verlag, 1977, p. 135) Wolff makes a more moderate suggestion, which is not dependent on the lexical features of Hebrew in comparison with other languages, as he argues that the book of Deuteronomy specifically negotiates questions of time and history by depicting the past as the dimension of time towards which the human being must be orientated in order to live in accordance with the covenant (pp. 132-135). I find it rather wonderful that Wolff's analys is does not make any sweeping claims about biblical time conception as a whole, focusing instead explicitly on the strategy and priorities in Deuteronomy's use of time as a theological theme.

10. Barr, Biblical Words for Time (London: SCM Press, 1962).

11. Barr, Biblical Words for Time, p. 141. Similarly, Marc Brettler argues that cyclical thinking dominates in a number of Hebrew Bible contexts. (Marc Brettler, "Cyclical and Teleological Time in the Hebrew Bible," in R.M. Rosen (ed), Time and Temporality in the Ancient World [Philadelphia: University of Pennsylvania Museum of Ar- 
Secondly, and perhaps more importantly, he showed that the underlying methodology of the lexical approach was not sound. Barr argued convincingly that it is rare to find a connection between the development of a language's lexical stock and specific notions in the philosophical system of those who speak the language. ${ }^{12}$ There is no easy correspondence between a lexical stock and the mindset of the language-speakers. Thus, for example, even if עr means something slightly different from $\chi \rho o ́ v o \varsigma$ and кaıрóৎ, we cannot assume a corresponding difference between the way that Hebrew and Greek language-speakers were able to think about time.

As a result of Barr's critical work, the field of biblical time conception was all but abandoned. ${ }^{13}$ It is only quite recently that scholars have once again started to engage in detail with this question. This brings us to Stern's 2003monograph on time and process in ancient Judaism. Stern does not assume the existence of a particular Hebrew understanding of time, which can be contrasted in some way to Greek or modern notions of time. Rather, he argues that the concept of time is entirely absent in the ancient Jewish material. It would have been impossible for the Hebrew Bible writers to discuss time as a subject in its own right, as they had no awareness of what "time" was. ${ }^{14}$ Stern's work poses an enormous challenge to explorations of biblical time conception, and it deserves to be discussed in detail. ${ }^{15}$

Fundamentally, Stern argues that neither the Hebrew Bible nor ancient Judaism more generally operated with a concept of time. His basic thesis is that "the concept of time as an entity in itself was unknown in ancient Jewish culture." Instead, "reality was experienced only in terms of processes." ${ }^{16}$ These would include the processes of observable, natural phenomena, as well as the many concrete processes of the human every-day life.

Process-thinking entails an engagement with reality "in empirical terms, as consisting of a multitude of discrete and concrete phenomena-activities, mo-

chaeology and Anthropology, 2004], pp. 111-128. See esp.pp. 113-118.) See also Arnaldo Momigliano, "His tory and the Concept of Time." History and Theory 6. Beiheft 6, 1966, p. 8 .

12. Barr, Biblical Words for Time, p. 116.

13. John R. Wilch was one of very few researchers to attempt a (language-based) analysis of biblical time-conception in the immediate wake of Biblical Words for Time. (J.R. Wilch, Time and Event: an Exegetical Study of the Use of 'et in the Old Testament in Comparison to Other Temporal Expressions in Clarification of the Concept of Time [Leiden: Brill, 1969]).

14. Stern, Time and Process, especially pp. 107-112.

15. Stern's focus is on the broader context of ancient Judaism, but he considers the situation in the Hebrew Bible to be the same as in the ancient Jewish material more widely and dedicates most of a chapter to the thinking on time - or lack thereof-in the biblical material.

16. Stern, Time and Process, p. 3. 
tions, changes, and events-occurring simultaneously or in sequence, i.e. processes." ${ }^{17}$ Discrete is an important word here: Stern does not imagine a cohesive system, in which the abstract term "process" simply replaces that of time. Instead, he argues, the authors of the ancient Jewish material would have conceived reality as a number of separate and concrete processes which could be coordinated when necessary. ${ }^{18}$ Examples of such processes may include the movement of the moon and the sun over the sky in the course of a month or a day, the process of sowing and harvesting, or the period of a woman's pregnancy. These are all concrete and real processes, according to which one may coordinate and plan activity, and Stern argues that they require no notion of time to function in this manner.

Stern considers the concept of time to be a cultural construct. This allows him to argue that it "need not be shared by all cultures of mankind. Indeed, there is no reason to assume the existence of this concept in any given culture unless there is positive evidence to support it." 19 In ancient Judaism, Stern argues, there is no such evidence available. He builds a significant part of his case on the absence of discussion on time as a subject in its own right in the ancient Jewish material, ${ }^{20}$ as well as the lack in ancient Hebrew of a term to describe time as a whole. ${ }^{21}$

Not only do the ancient Jewish sources refrain from discussing time explicitly; according to Stern, it is not even sensible to presume the presence of an implicit notion of time in this material. While, for example, the rabbinic writings care greatly for issues related to timing, calendar, and chronology, such interests are fully reconcilable with a process-orientated world-view. The processes referred to in this material are all concrete and tied either to the human or natural world. They do not depend on an abstract concept of time. ${ }^{22}$ If the ancient Jewish interest in timing or time-keeping focuses only on concrete processes, Stern argues, it is not warranted to read into the material an implicit interest in "the underlying, synthetic abstraction which we call 'time' or 'timedimension"." 23

There are two enormously productive notions in Stern's work. Firstly, he warns against importing modern-day notions of time into a corpus of ancient

17. Stern, Time and Process, p. 3.

18. Stern, Time and Process, p. 3.

19. Stern, Time and Process, p. 5.

20. He argues that the absence of discussion on time is not due to the genres used by the ancient Jewish authors. He notes further the absence of discussion of time in contexts where such discussion, according to his reading of the sources, would have been reasonable, such as in Rabbinic exegetical comments on Psalm 90,4; Job 9,25-6, or the Shema (Deut 6,4). (Stern, Time and Process, p. 31.)

21. He argues that זמן, which comes to mean "time" in medieval material carries the meaning only of "point in time" in the ancient Jewish material. (Stern, Time and Process., pp. 26-30.)

22. Stern, Time and Process, especially pp. 48-57 and pp. 59-69.

23. Stern, Time and Process, p. 4. 
material. ${ }^{24}$ It is extremely tempting to consider our concepts and notions universal, simply because it is how we are used to think. Stern sensibly demands that a detailed analysis of the ancient texts back up our discussion of their use of concepts such as time. Secondly, Stern's analysis of the literary choices made by the ancient Jewish writers, as well as by the writers of the Hebrew Bible specifically, offers an extremely useful insight into the linguistic and topical strategies which were used to explore temporality within a particular ancient context. The centrality in this exploration of natural processes and metaphors taken from the daily life of human beings is particularly interesting.

Nonetheless, Stern has not persuaded me that the concept of time was absent from the Hebrew Bible, and from ancient Judaism more widely. ${ }^{25}$ His argument regarding this absence of time moves on a number of levels, and in order to evaluate his basic thesis it is necessary to separate them out from each other. I want to look more closely at two of Stern's main approaches: firstly, he makes use of a linguistic-literary approach. He examines the Hebrew terms used to express issues which we consider temporal and debates the meaning of these terms. He discusses the use of certain expressions and metaphors, and he looks at the literary contexts in which (what seems to us to be) temporal concerns occur in order to investigate the scope of the claims made about, for example, calendar and history. Secondly, he builds on a number of anthropological studies of so-called "primitive" societies, in which anthropologists have found the concept of time to be lacking or pre-operational in character. ${ }^{26}$ This second methodological approach is particularly important to Stern's claim that

24. Stern, Time and Process, pp. 5-6.

25. Stern's general thes is has not tended to sway his academic reviewers either. Nicholas R.M. de Lange considers two parts of Stern's argument particularly unconvincing: "To accept Stern's conclusion it is necessary first to agree with him both that there is no trace of the Greek concept of time in the rabbinic writings and that it is legitimate to use 'the Jews' as a synonym of 'the Rabbis'." (p. 632) For example, he notes the circularity of thought when Stern excludes from the category of "Jews" those Jews who used concepts of time unproblematically. Catherine Hezner is more sympathetic towards Stern's work - especially his discussion of rabbinic literature specificallybut she takes is sue with the very general nature of his argument: like de Lange she argues that Rabbinic literature cannot be seen as representative of ancient Judaism as a whole. Diane Lipton approaches Stern's argument from a more philosophical perspective, casting doubt on the claim that there can be process without time, even if there could conceivably be time without process (p. 103). She furthermore discusses a number of biblical passages, arguing in favour of the presence in these texts of thinking on time. See: Nicholas R.M. de Lange, Journal of Theological Studies, Vol. 56, No. 2 (2005), pp. 628-633, Catherine Hezner, Journal of Jewish Studies, Vol. 56, No. 2 (2005), and Diane Lipton, Bulletin of the School of Oriental and African Studies, University of London, Vol. 68, No. 1 (2005), pp. 103-104.

26. The two approaches are not unrelated. Several of the anthropologists referred to by Stern make use of linguistic evidence themselves when evaluating the conception of time in specific, primitive-society contexts. For example, Christopher R. Hallpike, The Foundations of Primitive Thought (Oxford: Clarendon Press, 1979), refers repeatedly to Whorf's work on linguistic relativism, see for instance p. 346 and p. 357. 
the concept of time is not universal and that a society is able to function without knowing it. Taking my starting point in Stern's use of these two disciplines, I will consider how each of them may be applied to a discussion of biblical time.

\section{A Rose by Any Other Name: the Impact of Language upon Thinking}

Stern argues that if time were really present as a concept in the ancient Jewish material, it would have been discussed in some form or other. As such, his is very much an argument from silence:

"The concept of time (in a general sense) is so fundamental to our modern perception of reality that if the rabbis had shared it, one would expect them to have referred to it, just as we do frequently in our daily speech. Its absence in early rabbinic discourse (...) calls for an explanation. ${ }^{27}$

Seeking to demonstrate the non-presence of time in the ancient Jewish material, Stern discusses words which seem to describe time, as well as passages which appear to discuss temporality, arguing that it is in fact not time as such which is in view here. Rather, the word that later comes to mean "time" (זמן) refers in the ancient Jewish texts only to points in time and periods. ${ }^{28}$ Similarly, Stern argues, apparent discussions of temporal matters within the context of ancient Judaism are confined to depictions of concrete processes, points in time, and specific periods in time.

If discussions of points in time and specific periods do not indicate the presence of the concept of time, what, then, does Stern expect this concept to look like? Interestingly, he defines it quite narrowly:

"Time is only an abstract measurement of processes: it is, primarily, a way of expressing how long a process is. The modern concept of time as a general category, an autonomous flow, an empty extension, or a structure and dimension of the universe, is only a generalization and synthesis of all the discrete

27. Stern, Time and Process, p. 30. Differently than Stern, I would argue that genre conventions have to be taken into account here. The early rabbinic sources are, in Stern's own words, "devoid of philosophical discourse or scientific speculation." However, Stern argues, an appeal to genre in this case is unsound, because "it is perfectly possible for people who are neither philosophers nor scientists to discuss and make statements about the nature of time." (Stern, Time and Process, p. 30.) As a demonstration of this, Stern refers to the habitual references to time in every-day conversations today (pp. 30-31). However, there is a difference between it being possible to discuss time and it being necessary.

28. Stern, Time and Process, p. 29: “zeman is not a self-standing or 'pure' entity, a universal dimension, a flow, or a continuum. The concept of zeman, embracing only points in time and finite periods, is that of the 'time of things' $(. .$.$) zeman is the meas-$ urement of the occurrence and length of processes, natural events, and human activities." In the Hebrew Bible, a number of additional terms are used to refer to time. Stern discusses a few of these and argues these terms (עולם ברשית) are process-linked too, see pp. 108-112. 
time-measurements that can be made of the individual processes which we empirically experience. (...) Inasmuch as we tend to treat it, in modern culture, as existing and real (...) time often becomes a reified abstraction." 29

The definition of time as a reified abstraction (an abstraction which is treated as if it were real) raises a number of questions - primarily whether it is necessary to conclude that there is no concept of time in the Hebrew Bible if its texts do not treat time specifically as a "reified abstraction." Of course, if one reserves the term "time" for this particular way of conceptualizing temporal categories, it ceases to work as a description of what is happening in the biblical texts when they discuss, in other ways, issues relating to history, chronology, calendar, temporal order in creation, human temporality and so on. ${ }^{30}$ But why should this particular definition of time be privileged to the exclusion of all other ways of negotiating temporality? I wonder whether Stern's analysis here ends up doing exactly what it aims to avoid, namely imposing a modern category upon the ancient material. Based on our engagement with time today, he has chosen one particular definition of the concept of time. He then imports this concept to the ancient texts, evaluating them on the basis of their failure to engage with temporal themes as one would understand them within this specific modern framework.

If Stern is right that the ancient Jewish sources and the Hebrew Bible do not treat time as a reified abstraction, what he has shown is simply that this particular way of conceptualizing and engaging with time is not present in the material. He has not demonstrated that the ancient Jewish writers were unaware of time and unable to discuss the temporal dimensions of, for example, history, creation, and calendar. Might his discussion of the lexicon and grammatical structure of Hebrew serve him better?

Stern dedicates quite a lot of attention to the discussion of the "real" meaning of time-words like Tמן. Thus for example, he shows that there is no word for time as a general notion in biblical and rabbinic Hebrew. ${ }^{31} \mathrm{He}$ also discusses grammatical constructions in Hebrew, and though he states that the grammatical set-up of a language does not determine thinking, he nonetheless

29. Stern, Time and Process, p. 18.

30. Ralph M. Rosen's comments on time conception in ancient cultures are relevant here. He states that "there is no reason to suppose that we can legitimately articulate a comprehensive, monolithic pre-modern or ancient conception of time and temporality." (p. 3) (Ralph M. Rosen, "Ancient Time across Time," in R.M. Rosen (ed), Time and Temporality in the Ancient World [Philadelphia: University of Pennsylvania Museum of Archaeology and Anthropology, 2004], pp. 1-9.) Instead, he argues, p. 2, that both ancient and modern cultures evidence a number of ways of conceptualizing time: "the very notion of existence implies some sense of time, whether it is a static time, time that flows in one direction like a river or that moves like a continuous circle; time that implies endless futurity or an ever-growing past."

31. I concede this quite happily. At the very least, there are no words in biblical Hebrew which always and unequivocally refer to time as a general concept. As Barr noted, however, it is difficult to think of a word in any language which does this. (Barr, Biblical Words for Time, p. 97.) 
maintains that the preference for aspect over tense in Hebrew may reveal something about the thinking of the language speakers. ${ }^{32}$ To some extent, then, Stern presupposes that there is a correlation between language and thinking, so that the former reveals the latter. As discussed above, the proponents of the lexical approach would argue in favour of a similar correspondence between a language and the conceptual structures of the language-speaker. Stern does not, however, return to this approach. He is not only - and not even primarilyinterested in the lexical stock of Hebrew. Nonetheless, both approaches rely in part on the brand of linguistics known as linguistic relativism.

A particularly famous product of linguistic relativism is Benjamin Lee Whorf's discussion of the Amerindian language Hopi and its expression of temporal concepts. Whorf argued that the peculiar character of Hopi depictions of time, especially the limited temporal vocabulary, shaped and affected adversely the Hopi-speakers' ability to conceptualize time. ${ }^{33}$ As a result Hopi language speakers have "no general notion or intuition of TIME as a smooth flowing continuum in which everything in the universe proceeds at an equal rate..." ${ }^{34} \mathrm{~A}$ Whorfian approach to the Hebrew Bible would explore the temporal vocabulary, and the ways in which time is grammaticalized in Hebrew, in order to gain insight into the capacity of the language-speakers to think about time. If, for example, biblical Hebrew lacks a term to describe time abstractly, it would be reasonable to assume that this would adversely affect the biblical writers' ability to think about time abstractly. If there is no real tense system in Hebrew, this too would reveal something about their understanding of time. ${ }^{35}$

Stern distances himself from what he terms "lexical determinism,"36 but nonetheless he expects the Hebrew language to reflect the conceptual structures among the language-speakers. On the one hand, he acknowledges that even if Hebrew lacks a general word for time, this "should not have prevented

32. Stern, Time and Process, p. 24: "preference for aspect and modality in the verbsystemof a language (...) may suggest that aspect of event and modality of statement are conceptually more important, to the language-users, than time of event." And further p. 25: "The fuzziness or absence of a tense system in many languages may thus serve to confirm that the concept of a temporal dimension is not neces sary for a cogent experience and interpretation of lived reality."

33. According to Benjamin Lee Whorf, Hopi language contains "no words, grammatical forms, constructions or expressions that refer directly to what we call 'time,' or to past, present, or future..." (Benjamin Lee Whorf, Language, Thought, and Reality: Selected Writings of Benjamin Lee Whorf. Edited and with an introduction by J. B. Carroll [Cambridge, MA: MIT Press, 1956], p. 57.)

34. Whorf, Language, Thought, and Reality, p. 57.

35. See also Guy Deutscher, Through the Language Glass: Why the World Looks Different in Other Languages (London: Arrow, 2011), p. 144: "One idea has proved particularly resilient to the onslaught of fact or reason: the argument that the tense system of a language determines the speakers' understanding of time. Biblical Hebrew has offered particularly rich picking" due to its "allegedly tenseless verbal system."

36. Stern, Time and Process, p. 13. 
the rabbis or others from conceptualizing this notion, or from giving it some form of verbal or other expression." ${ }^{37}$ On the other hand, he considers the fact that they did not do this to be of great importance. If the notion of time in general is never described in the ancient Jewish material, Stern argues, this indicates that they did not need the concept. At a glance, this argument differs significantly from that of Whorf, but perhaps the two modes of thinking about the relationship between language and time are not as unrelated as it would initially seem. While Whorf argued that language determines thinking, Stern argues that language reveals thinking: to Stern it remains significant that does not mean "time" exactly, and that no other expression was devised by the ancient Jews which carried this particular meaning. There is a degree of linguistic relativism in this argument too, though it is not as extreme a proposition as Whorf's. Stern's approach to the Hebrew language remains dependent upon the notion that we can expect a relationship between the lexicon and grammar of a language and the mindset of the language-speakers, and in such a way that the former tells us something about the latter.

Whorf's approach has been viciously attacked within linguistics. His concrete case studies have been refuted, ${ }^{38}$ and the linguistic relativism, on which his work based itself, has lost much support. The oft-quoted statement by Roman Jakobson is telling of the shift in opinion which has taken place within linguistic research:"Languages differ essentially in what they must convey and not in what they may convey." 39 Thus, in any given language there are things which must be communicated. At the same time, however, it is still possible to think and express things which must not necessarily be communicated in a given language. For example, I have to use the future tense if I want to discuss my plans for the coming year in French. At the same time, however, I am able to tell my Danish friends about my future plans too, despite the fact that Danish has no proper future tense.

37. Stern, Time and Process, p. 30.

38. Ekkehart Malotki, p. 632, states that: "the Hopi Indians lack neither an elaborate consciousness of time nor its reflection in their speech..." (Ekkehart Malotki, Hopi Time: a Linguistic Analysis of the Temporal Concepts in the Hopi Language [Berlin and New York: Mouton Publisher, 1983]). Malotki also emphasizes, however, that the Hopi "sense of time, or the role that time plays in their lives and culture, does not correspond to ours. Nor would one expect the two to be identical. (...) although we detect a great deal of overlap, the influence of his torical, social, religious, environmental, and otherfactors has definitely shaped, and is still shaping, the individual temporal needs of each group." Malotki argues more generally, p. 630, that some domains of thinking "are experienced universally by all mankind (...) One such domain is time, a fundamental experience conceptualized by every human mind and processed linguistically by all languages to some degree or other." See also Alfred Gell, The Anthropology of Time: Cultural Constructions ofTemporal Maps and Images (Oxford and Dulles, VA: Berg, 1992), p. 127, and Steven Pinker, The Language Instinct: the New Science of Language and Mind (London: Allen Lane, 1994), p. 63.

39. Roman Jakobson, "On Linguistic Aspects of Translation," in Reuben A. Brower (ed), On Translation (New York: Oxford University Press, 1966), p. 236. 
It is perfectly valid to investigate which aspects of temporal experience must necessarily be conveyed in biblical Hebrew. ${ }^{40}$ What one cannot claim on the basis of a linguistic analysis, however, is the inability of the Hebrew Bible authors to conceptualize and discuss the notion of time. If language does not impact and reveal thinking in the way suggested by Whorf, Stern's analysis of the "real" meaning of words that mean something like time does not tell us very much about the ability of the ancient Jewish writers to think about time. We cannot use linguistic evidence to challenge the conceptualizing capacity of the language speakers and thus disprove the presence of particular concepts among them.

Turning now to anthropological studies of the engagement with time in "primitive" societies, I want to consider what this discipline can contribute to the discussion of time and cognition.

\section{Cultural Relativism and Thinking on Time}

Making use of ethnographic studies which question the presence of the concept of time in a number of specific, modern-day societies, ${ }^{41}$ Stern argues that a similar unawareness characterized ancient Judaism. ${ }^{42}$ In order to evaluate the validity of this claim, one question in particular must be asked; namely what kind of cultural relativism regarding time can be demonstrated through ethnographic studies? That is, what can ethnography discover about the conception of time in a given society? And how far is it possible to use ethnographic studies to demonstrate divergences in the basic time-conception of different societies?

According to Stern, "ethnographers have found that in many-if not all'primitive' or non-modern societies, the concept of time as an entity in itself simply does not exist." The members of such societies do not operate with "the

40. And even here it may be wise to remember, with Jacobson ("On Linguistic Aspects," pp. 235-236) that: "the grammatical pattern of a language (as opposed to its lexical stock) determines those aspects of each expression that must be expressed in the given language."

41. The anthropologists referred to especially are Edwan Evan Evans -Pritchard, Pierre Bourdieu, and Christopher Hallpike. Christopher Hallpike (The Foundations of Primitive Thought [Oxford: Clarendon Press, 1979]) does not exactly argue that there is no concept of time in pre-technological societies. Rather, he suggests, on the basis of psycho-linguistics, that even adult members of these societies have only a pre-operational understanding of time. For a discussion of this claim and the psycho-linguistic studies on which Hallpike builds, see Gell, The Anthropology ofTime, pp. 97-117.

42. Stern, Time and Process, p. 7, states that he is "not using ethnographic material to suggest any particular affinity between ancient Judais $m$ and the present-day societies ethnography describes. All I am suggesting is that they shared a similar view of time and process, not because this view is intrinsically primitive, but simply as an alternative to the modern Western world-view." 
notion of 'pure time' or an overarching 'time-dimension'," and they are unfamiliar with the "concepts of time-saving and time-management." 43 For example, Stern refers to Edward Evan Evans-Pritchard who argues in the context of his work on the Nuer people that "the Nuer system of time-reckoning (...) is a series of conceptualizations of natural changes" in which "the selection of points of reference is determined by the significance which these natural changes have for human activities." 44

This statement occurs in the course of Evans-Pritchard's analysis of oecological time among the Nuer - a cyclical mode of time-reckoning, the length of which is a year's worth of seasons. Evans-Pritchard argues that oecological time is tied to concrete processes - such as the phases in the daily work with the cattle, changes in vegetation, and so on. ${ }^{45}$ However, he goes on to discuss another type of time concept among the Nuer: structural time, which is designed to deal with periods of time of a longer duration than a year. Stern does not refer to this second part of Evans-Pritchard's study of Nuer time, which is unfortunate, since structural time is described as being much more abstract than oecological time. ${ }^{46}$ Structural time is counted and calculated according to "sets" of generations, each lasting approximately ten years, instead of according to real, observable processes. To Evans-Pritchard, then, Nuer time reckoning is not exclusively concrete, dependent only on concrete natural and human processes. Rather, larger stretches of time have to be worked out according to more abstract processes. ${ }^{47}$

During the course of his discussion, Evans-Pritchard remarks that, to the Nuer, " $(t) i m e$ has not the same value throughout the year. (...) In the drought the daily time-reckoning is more uniform and precise while lunar reckoning receives less attention..."48 As I read Evans-Pritchard, the implication is that the practical organization of time-measurement in Nuer-land changes with the seasons and their differing demands. This observation demonstrates well the way in which an ethnographic study may inform us about culturally specific ways of ordering and making sense of time. However, Evans-Pritchard's statement could possibly also be read in another sense; namely as an argument that,

43. Stern, Time and Process, p. 12.

44. Evans-Pritchard, The Nuer: a Description of the Modes of Livelihood and Political Institutions of a Nilotic People (New York and Oxford: Oxford University Press, 1940), p. 104. (Also quoted by Stern, Time and Process, p. 14.)

45. Evans-Pritchard, The Nuer, p. 96 and p. 102

46. For example, Evans-Pritchard argues: "the movement of structural time is, in a sense, an illusion, for the structure remains fairly constant and the perception of time is no more than the movement of persons, often as groups, through the structure. Thus age-sets succeed one another for ever, but there are never more than six in existence and the relative positions occupied by these six sets at any time are fixed structural points through which actual sets of persons pass in endless succession." (Evans Pritchard, The Nuer, p. 107.)

47. In The Anthropology of Time, pp. 17-18, Gell also comments on the abstract character of Nuer structural time as described by Evans-Pritchard.

48. Evans-Pritchard, The Nuer, p. 103. 
to the Nuer, time does in fact change character according to the phases of the year; that, according to the metaphysical logic of the Nuer, time in itself genuinely functions differently in the drought-season than in other seasons. If this were the intended sense, that would be quite problematic. Alfred Gell's discussion of the purview of time-anthropology shows why.

While maintaining that different societies constitute their world in different ways, and that this cultural relativism includes their handling of time, Gell argues that it is mistaken "to suppose that cultural systems of transmitted beliefs and representation are pervaded with a deep 'cultural logic', which sets the outmost limits on the 'thinkable', for members of a given culture." Ethnography is not "the kind of enterprise which could result in the discovery of new ways of constituting the world in its general or categorical aspects..." ${ }^{49}$ For example, it is a problematic claim that ritual is designed to make time actually go into reverse. Similarly, it would be a problem to say that to the Nuer-mind time actually passes differently during the drought-season because it is being handled differently in this period.

I want to suggest that Stern's claim about the absence of time in ancient Judaism overreaches in a similar way. He does not simply say that the ancient Jewish writers saw no cultural, ritual, or agricultural need to engage with time abstractly, or that the focus in the ancient Jewish material is on those concrete representations of temporal matters which were necessary to the purposes of the writers and their communities. Rather, he bases a claim about time in itself - namely, that it was absent as a conceptual category — on ethnographic studies of time-organization. By doing so, he enlists ethnography to make a case for which it is not well-equipped. As Gell states, the "limitations of ethnography as a descriptive genre" must be respected. The anthropologist should refrain from making "metaphysical statements." Statements about the constitution of the world or the "kind of place the world in general must considered to be" belong to the discipline of philosophy, not anthropology. ${ }^{50}$

Anthropological studies uniquely enable us to examine the use of time-talk in relation to the social structures in a given society. The fact that people speak differently about time, organize their calendars differently, etc., demonstrates that different areas of concern are important and useful to the societal organization in different cultural contexts. It says nothing about what time actually is or is fundamentally perceived to be.

\section{The Temporal Coordination of Processes in the Hebrew Bible}

Is it possible to render likely the presence of temporal awareness in the Hebrew Bible, even if time is rarely discussed explicitly in this corpus? So far I have mainly discussed what cannot be claimed about (the absence of) time in the Hebrew Bible and ancient Judaism on the basis of linguistic and anthropological work. At this point, however, I want to present an argument in favour of the biblical writers' ability to make use of the notion of time. This argument is

49. Gell, The Anthropology of Time, p. 55.

50. Gell, The Anthropology of Time, p. 55. 
not dependent on the biblical writers' discussion of issues such as history, calendar, creation, mortality, or eschatology. While I am convinced that the widespread interest in issues related to these themes indicates the ability of the biblical writers to conceptualise temporal ideas, Stern would assign such discussion to the realm of process thinking. Differently, I hope that my argument in this section operates on premises that Stern and the anthropologists, on whose work he builds, may be able to accept.

Gell argues that the "whole point" of the abstract category of time is "that it provides the means for the relative unification of otherwise diverse categories of processes." We use the category of time to coordinate discrete processes, some of which, aside from their position on some sort of temporal axis, are not obviously related: "Time (...) allows for the co-ordination of diverse processes; biological processes with social ones, psychological or subjective processes with objective, clock-timed ones, and so forth." ${ }^{51}$

It seems plausible to me that a successful coordination of different processes in time indicates an understanding of the specifically temporal aspect of process. In other words, coordinating events according to a temporal axis requires a concept of time. This is important because the authors of the Hebrew Bible constantly demonstrate the ability to coordinate processes in time. For example, the writer of Amos 1,1 conveys the simultaneity of a particular point in time during the reign of two kings of different dynasties with the year preceding "the earthquake" by two years. The synchronisms in the Books of Kings achieve something similar. Different processes, referring to different modes of organizing events along a time-line, are here coordinated. Such examples imply that the Hebrew language users were well aware of the specifically temporal aspect of process. ${ }^{52}$

Another example of the ability to coordinate discrete processes in time can be found in Joshua 10,12-13. Here the narrator tells of a miracle: as Israel prepares to fight the Amorites, God lets the sun stand still in the heaven. It does not set until Israel has won the battle. ${ }^{53}$ Two discrete processes are here coordinated: the pace of the sun, which extraordinarily slows down, and the events

51. Gell, The Anthropology ofTime, p. 316.

52. In her review of "Time and Process," Lipton too refers to a number of biblical texts in order to counter Stern's claim that the ancient Jews did not possess a concept of time. Rather than turning to the intersection of process and time, however, she demonstrates that there are in fact examples in the Hebrew Bible of time being discussed as something distinct from process. Specifically, she refers to the creation epic in Genes is 1:1-2:4a: "Surely the sheer emptiness of God's seventh day of creation (as well as the recommended human imitation of it) highlights time as an entity distinct from event and process!" (p. 104) This strikes me as an entirely reasonable point. (Diane Lipton: Bulletin of the School of Oriental and African Studies, University of London, Vol. 68, No. 1 (2005), pp. 103-104.)

53. "On the day when the LORD gave the Amorites over to the Is raelites, Joshua spoke to the LORD; and he said in the sight of Israel, "Sun, stand still at Gibeon, and Moon, in the valley of Aijalon." And the sun stood still, and the moon stopped, until the nation took vengeance on their enemies. Is this not written in the Book of Jashar? The sun 
of the battle which would not have been able to take place within the normal hours of daytime. This particular example of temporal coordination parallels a real-life encounter between the anthropologist Gell and an Umeda man who seemed unable to grasp that walking faster would make it easier for him to get home before dark. In fact, Gell does not believe that the Umeda man was unable to perform the necessary temporal coordination to work this out, but blames miscommunication for the strange situation. ${ }^{54}$ He notes, however, that another anthropologist, Christopher Hallpike, has used his account of this encounter as an example of a pre-operational understanding of time: $:^{55}$ understood within the context of pre-operational time-conception, the problem for the Umeda man would be that he is unable to coordinate two discrete processes temporally (that of walking a certain distance and that of the sun setting). ${ }^{56}$ Conversely, as shown, biblical writers, including the author of Joshua 10:12-13, easily coordinate seemingly unrelated processes according to their placement on a temporal axis.

\section{Alternative Approaches to Time in the Hebrew Bible}

In this article I have shied away somewhat from grappling with the philosophical question of whether or not time is universal to the human experience. Instead, I have argued that the disciplines of linguistics and anthropology, through which the time-conception in the Hebrew Bible is frequently explored, are not very well-suited to answering this question. These disciplines do not allow us to conclude that time is absent in the Hebrew Bible or, indeed, ancient Judaism more widely. Regarding the Hebrew Bible specifically, I have suggested that the effortless coordination in the biblical material of discrete processes according to a temporal axis favours the conclusion that its writers did in fact possess an awareness of time.

Thus, I am strongly in favour of retaining the category of time when engaging with the biblical interest in calendar, history, mortality, creation, eschatology and so forth. Both Stern and the proponents of the lexical approach have made some enormously interesting observations about the ways in which the biblical authors discuss these themes. As we have seen, Stern underlines in particular the centrality of process in the ancient Jewish and biblical materialthe use of specific natural processes, as well as processes taken from the daily life of human beings - to explore the temporal aspects of human life. Somewhat similarly, researchers such as Marsh and Wheeler Robinson pointed out that biblical depictions of time tend to tie temporal experience to concrete events, activities, and processes. Instead of dissuading us from approaching the

stopped in midheaven, and did not hurry to set for about a whole day" (NRSV translation).

54. Gell, The Anthropology of Time, pp. 113-116.

55. Gell, The Anthropology of Time, p. 115, as well as p. 102, where he states: “According to Hallpike, the ability to abstract time as a computable aspect of all processes, in terms of duration, succession and simultaneity, is an aptitude not possessed by members of pre-technological societies."

56. Gell, The Anthropology ofTime, p. 115. 
topic of biblical time, these observations encourage further engagement with the depictions of temporal themes in the biblical material.

It is important to remember that the biblical writers, when seeking to engage with the difficult subject of time, do not only refer to concrete processes in a literal manner. Such processes are also used as images and metaphors. One example is Qohelet's repeated use of the phrase "under the sun". ${ }^{57}$ when the book's author uses this phrase to describe human life, he uses the image of a single day and the sun's daily journey across the sky to depict the temporal aspect of human life in its entirety. The frequent use of metaphorical depictions in the Hebrew Bible presents us with a fascinating access-point into the strategies used by the biblical writers to engage with different aspects of temporal existence. It invites us to ask why, for example, the sun is such an appropriate temporal metaphor for the author of Qohelet. What may this image, taken from the world of concrete, natural phenomena, add to the depiction of time in this biblical book?

Instead of claiming that the biblical writers could only think about time in terms of process or as something concrete, I would ask which priorities and concerns may have prompted them to choose a particular depiction of time. For example, how are the text-writers interested in time as something concrete? Which particular processes do they make use of to depict issues related to time, and what aspects of temporal experience do the chosen processes privilege? An exploration of preferred temporal expressions, metaphors, and ideas may help us see which parts of the human temporal experience it was pressing to discuss. We may also consider the extent to which cultural and ritual needs reinforce the popular modes of depicting time and temporality.

I would also be interested in potential changes to the engagement with time over the course of the long period, during which the Hebrew Bible was written. It may be that new genres, such as, for example, apocalyptic vision, require new temporal images. ${ }^{58}$ Do the biblical writers innovate when they choose processes as images to describe the experience of time? Could different depictions of time come into conflict with each other? For example, we are used to describe the conflict in second temple Judaism between the solar and lunar calendars as indicative of differing theological interests. This is surely right, but might something additional be gained if we also consider the potential of each

57. The expression accounts for 29 out of 35 references to the sun in the book of Qohelet.

58. Especially interesting in this context are, I think, the discussions of time in the book of 1 Enoch-here a wide range of temporal themes take to the stage, both within the depictions of the visionary experience and in the overviews of history and cosmology offered in the Astrological Book, the Apocalypse of Weeks, and the Animal Apocalypse. 1 Enoch evidences a diverse interest in temporal themes, which appear to have been used across the Enoch tradition to grapple with the community's situation. (See for example George W. E. Nickelsburg, "Enoch' as Scientist, Sage, and Prophet: Content, Function and Authorship in 1 Enoch," in Society of Biblical Literature Seminar Papers, 38 [Atlanta, GA: Scholars Press, 1999], pp. 203-230, and especially p. 218 219.) 
calendar - and the literary formulations and depictions of them both - to function as temporal metaphors?

A final area of interest to me would be to examine what happens when the standard depictions of themes related to time prove insufficient. How do the Hebrew Bible authors approach more abstract notions of time, for examplesuch as the differing temporal reality of God and human being, which is tackled poetically in Psalm 90? What linguistic strategies are used when time itself becomes an area of reflection and a need is felt to engage directly with the properties of this part of our existence? Here I want to use the book of Qohelet as an example once again, because it provides an excellent example of a Hebrew Bible attempt to engage abstractly with the concept of time. The author of this book considers at length the effects of the temporal order on humankind. He stretches traditional language regarding time to its breaking-point in order to consider not only the temporal reality, but also the human thinking on this reality. ${ }^{59}$ If researchers like Stern are looking for an explicit discussion of time in the Hebrew Bible, the book of Qohelet is an excellent place to go. It is, however, far from the only biblical engagement with temporal thinking. The stock images, the metaphorical application of concrete processes, and the genre-dependent depictions of temporal experience equally deserve to be discussed under the heading of time.

59. For a detailed discussion, see Machinist's brilliant article on the language of fate and time in the book of Qohelet: "Fate, miqreh, and Reason," as well Mary Mill's discussion of time in her monograph on Qohelet and autobiography (Mary E. Mills: Reading Ecclesiastes: A Literary and Cultural Exegesis. (Heythrop Studies in Comtemporary Philosophy, Religion and Theology [Aldershot: Ashgate, 2003]). Michael V. Fox's 1999-commentary on the book contains an insightful discussion of Qohelet's treatment of the notion of "proper time," see especially pp. 198-200. (M.V. Fox: A Time to Tear Down and a Time to Build up: a Re-Reading of Ecclesiastes [Grand Rapids and Cambridge: William B. Eerdmans, 1999]). 